\title{
SENSITIFITAS UDANG Litopenaeus stylirostris DAN Penaeus monodon TERHADAP INFEKSI SEMBV (SYSTEMIC ECTODERMAL AND MESODERMAL BACULOVIRUS)
}

\section{SENSITIVITY OF Litopenaeus stylirostris AND Penaeus monodon AGAINST SEMBV (SYSTEMIC ECTODERMAL AND MESODERMAL BACULOVIRUS) INFECTION}

\author{
A. Taslihan ${ }^{*}$, R. Handayani ${ }^{*}$, Suryati $\left.{ }^{*}\right)$ dan N. Fahris ${ }^{*}$
}

\begin{abstract}
Study on sensitifity of two shrimps species, there were blue shrimp (Litopenaeus stylirostris) and giant tiger shrimp (Penaeus monodon) against local isolat of SEMBV (systemic ectodermal and mesodermal baculovirus) has been undertaken. The objective of the study were to know sensitivity level of the two shrimp species to virus that cause serious disease namely WSDV (white spots disease virus). Result from the study showed that both shrimps are sensitive to the virus. Inoculating virus through injection caused transmission faster than that by feeding shrimp with infected carcass. Blue shrimp also showed relatively sensitive to SEMBV then that of giant tiger prawn.
\end{abstract}

Key words: Lytopenaus stylirostris. Penaeus monodon, SEMBV.

\section{Pengantar}

Udang putih (Litopenaeus stylirostris) termasuk ordo Penaeid, Famili Penaidae, Genus Penaeus dan Sub. Genus Litopenaeus. Udang ini memiliki beberapa nama, yaitu Blue shrimp (Inggris), Crevette bleue (Perancis), Camaron azul (Spanyol), Camaron blanco (Colombia, Costarica, Equador, Meksiko, Nikaragua, Panama dan Peru), Mexican white shrimp (Amerika). Udang ini dapat mencapai panjang $230 \mathrm{~mm}$. Udang putih Litopenaeus stylirostris merupakan udang asli dan terdistribusi di Belahan Timur Samudra Pasifik, dari Punta Abrejas (Mexicos Baja California) hingga Paita, Peru. Merupakan udang yang hidup di perairan dangkal, dan hidup pada kedalaman air mencapai lebih dari 27 meter dengan dasar lumpur, pasir atau dasar berliat. Udang biru dikenal merupakan spesies yang berkualitas baik dengan daging yang kenyal dan rasa yang lezat.

Toleransi terhadap lingkungan adalah kemampuan hidup pada toleransi suhu rendah, mencapai $12^{\circ} \mathrm{C}$ selama 72 jam dengan tanpa terjadi kematian pada ukuran juvenil (5-7 gram). Kisaran suhu tertinggi adalah mencapai $37^{\circ} \mathrm{C}$, sedangkan suhu ideal untuk pertumbuhan adalah antara $24-30^{\circ} \mathrm{C}$. Toleransi salinitas adalah antara 5-55 ppt, dengan kisaran ideal untuk pertumbuhan antara $24-45$ ppt.

Sehubungan dengan introduksi udang tersebut ke wilayah perairan Republik Indonesia ada dua kekhawatiran, yaitu (1) introduksi patogen baru yang ikut terbawa oleh spesies kultivar tersebut, yang bersifat virulen terhadap spesies lokal dan (2) spesies introduksi rentan terhadap patogen yang terdapat di lingkungan yang baru. Pada saat ini budidaya udang di tanah air terimbas oleh virus mematikan yaitu SEMBV (systemic ectodermal and mesodermal baculovirus) yang mengakibatkan tingkat kematian yang tinggi di tambak sehingga berakibat pada kegagalan panen dan kerugian yang sangat besar.

Uji transmisi merupakan salah satu metode pendekatan yang dapat dilakukan untuk mendapatkan data tentang sifat-sifat dari patogen bawaan atau lokal yang kemungkinan membahayakan spesies

\footnotetext{
*) Balai Besar Pengembangan Budidaya Air Payau, Jepara
} 
lokal atau spesies baru. Beberapa kajian terhadap uji transmisi telah dilakukan oleh Balai Besar Pengembangan Budidaya Air Payau Jepara terhadap Vibrio harveyi, $V$. alginolyticus, $V$. parahaemolyticus, $V$. anguillarum, baik terhadap udang windu maupun ikan. Demikian juga uji transmisi terhadap penyakit viral juga telah dilakukan, terutama terhadap SEMBV (systemic ectodermal and mesodermal baculovirus).

\section{Bahan dan Metode}

\section{Sumber isolat virus}

Isolat virus didapatkan dari udang yang mengalami infeksi SEMBV dengan ciri adanya bercak putih dan juga dikonfirmasi dengan uji PCR (polymerase chain reaction). Untuk membuat larutan injeksi dilakukan dengan cara daging udang terinfeksi virus dihomogenisasi dalam PBS, kemudian disentrifugasi, dan penyaringan supernatan dengan penyaring $0,2 \mu \mathrm{m}$. Untuk perlakuan melalui pemberian pakan disiapkan daging udang. Selanjutnya hasil penyaringan (filtrat) dialiquot menggunakan tabung mikro berkapasitas $1,5 \mathrm{ml}$ dan daging udang selanjutnya disimpan $-40^{\circ} \mathrm{C}$ hingga dipergunakan.

\section{Uji Transmisi}

Pengujian transmisi melalui dua metode: yaitu secara injeksi dengan filtrat yang didapatkan sebelumnya dan pemberian karkas udang terinfeksi virus. Udang yang dipergunakan untuk pengujian adalah udang yang didapatkan dari petakan pemeliharaan Balai Besar Pengembangan Budidaya Air Payau Jepara dengan berat \pm 10 gram. Sebanyak 30 ekor udang untuk masing-masing spesies diinjeksi dengan $0,1 \mathrm{ml}$ filtrat. Sedangkan untuk transmisi melalui pakan dilakukan dengan sebanyak 30 ekor udang rostri diberi pakan dengan 3 ekor udang terinfeksi virus yang dipotongpotong. Udang sebelumnya tidak diberi pakan selama 24 jam. Sedangkan untuk udang windu sebanyak 10 ekor diberi pakan 1 ekor udang terinfeksi virus. Pengamatan kematian udang dilakuan 1 , $3,6,12,24,48,72$ dan 96 hingga 168 jam pasca perlakuan. Kontrol dilakukan dengan injeksi udang menggunakan PBS dan pemberian pakan dengan udang yang tidak terinfeksi virus.

\section{Uji PCR}

Pengujian dengan PCR menggunakan metode yang telah ada (Lo et al., 1998). Selengkapnya pengujian meliputi Ekstraksi fenol, sebanyak 0,2 gram jaringan otot, dimasukkan dalam tabung eppendorf kemudian dihancurkan dengan mortar, setelah ditambahkan bufer digesti (50 mM Tris- $\mathrm{HCl} \mathrm{pH}$ 7,4, $10 \mathrm{mM} \mathrm{NaCl}, 10$ mM EDTA, $1 \%$ SDS) sebanyak $400 \mu \mathrm{l}$ dan ditambahkan proteinase $\mathrm{K}$ hingga konsentrasi akhir $300 \mu \mathrm{g} / \mathrm{ml}$ kemudian tabung diinkubasi dalam shaking inkubator atau inkubator distel pada suhu $37^{\circ} \mathrm{C}$ selama 1 jam. Ditambah fenol dengan volume sama, kemudian disentrifus pada kecepatan $11.600 \mathrm{~g}$ selama 5 menit, fase air dipisahkan dan dipindah ke eppendorf yang baru, kemudian ditambahkan fenol CIAA dengan volume yang sama, fenol divorteks dan disentrifus dengan kecepatan $11.600 \mathrm{~g}$ selama 5 menit. Fase air diambil secara hati-hati dan dipindahkan ke tabung baru, selanjutnya ditambahkan $1 / 10$ volume $\mathrm{Na}$-asetat $2 \mathrm{M}$ $\mathrm{pH} 4,8$ dan $2 x$ volume etanol absolut dingin dan diinkubasikan dalam freezer, tabung diputar-putar, dan disentrifuse pada kecepatan $11.600 \mathrm{~g}$ selama 5 menit untuk mengendapkan pellet, larutan dibuang dengan cara dituangkan selanjutnya dikering-anginkan. Tahap akhir adalah melarutkan pelet dalam bufer TE (Tris 100 $\mathrm{mM} \mathrm{pH} \mathrm{8,0,} \mathrm{EDTA} \mathrm{0,5} \mathrm{mM} \mathrm{pH} \mathrm{8,0).}$

Amplifikasi gen, dilakukan dengan cara membuat campuran $(50 \mu \mathrm{l})$ terdiri dari $5 \mu \mathrm{l}$ bufer PCR 10x $(500 \mathrm{mM} \mathrm{KCl}, 100 \mathrm{mM}$ Tris-Cl pH 8,4, $1 \mathrm{mg} / \mathrm{ml}$ gelatin), atau PCR buffer yang sudah tersedia pada saat membeli Ensim, $5 \mu$ l larutan dNTP 10x (terdiri dari dATP, dTTP, dCTP dan dGTP dengan konsentrasi masing-masing sebesar $2 \mathrm{mM}$ ), $2,5 \mu \mathrm{l} \mathrm{MgCl}_{2}$ pada 
konsentrasi $20 \mathrm{mM}$, masing-masing $1 \mu \mathrm{l}$ larutan oligonukleotida primer sense dan antisense dengan konsentrasi $20 \mu \mathrm{M}$, ensim Taq DNA polymerase 0.5 unit. Amplifikasi dilakukan pada 4 tahap, yaitu hot start, siklus, extra extention, dan pendinginan. Siklus I (1x siklus). Hot start $=95^{\circ} \mathrm{C}$ selama 5 menit. Siklus II (30 siklus) Denaturasi $=94^{\circ} \mathrm{C}$ selama 30 detik Annealing $=52,5^{\circ} \mathrm{C}\left(1^{\text {st }}\right.$ step PCR $)$, menggunakan primer $\mathrm{F} 1$ dan $\mathrm{R} 1$; untuk $2^{\text {nd }}$ step nested PCR menggunakan suhu annealing $54^{\circ} \mathrm{C}\left(2^{\text {nd }}\right.$ step PCR $)$ extention = $72^{\circ} \mathrm{C}$ selama 1 menit, Siklus III (1x siklus), Extra extension $=72^{\circ} \mathrm{C}$ selama 5 menit, Pengamatan produk amplifikasi dilakukan secara elektroforesis pada agarose dengan konsentrasi $2 \%$ mengandung ethidium bromide $0,5 \mu \mathrm{g} / \mathrm{ml}$, dengan kuat arus 100 volt dalam bufer TBE (Tris 89 $\mathrm{mM}$, Boric acid $89 \mathrm{mM}$, EDTA $2 \mathrm{mM}$ ).

\section{Hasil dan Pembahasan}

Uji patogenisitas virus SEMBV terhadap udang rostris Litopenaeus stylirostris dan udang windu Penaeus monodon

Pengujian tingkat patogenisitas virus bercak putih (SEMBV) menunjukkan bahwa udang $L$. stylirostris ternyata juga peka terhadap infeksi virus ini. Rute infeksi secara injeksi intramuskular memberikan reaksi yang lebih cepat dibandingkan dengan rute secara oral, yaitu pemberian melalui pakan yang terinfeksi virus (Tabel 1).

\section{Uji PCR}

Uji PCR dipergunakan untuk uji konfirmasi. Dari udang yang mengalami kematian menunjukkan hasil PCR positif, dengan terbentuknya band yang sesuai yang berarti bahwa udang mengalami kematian akibat infeksi virus.

Diantara beberapa jenis baculovirus, maka virus penyebab penyakit bercak putih merupakan jenis yang diketahui paling ganas terhadap udang windu. Kerugian dilaporkan mencapai jutaan dolar Amerika setiap tahunnya akibat wabah penyakit ini. Beberapa kawasan tambak terpaksa tidak ditebari udang karena khawatir mengalami serangan virus. Gejala serangan diantaranya adalah timbulnya bercak putih (meskipun tidak selalu), terjadi kematian menurut deret logaritmis dari hari ke satu ke hari berikutnya hingga kematian mencapai $100 \%$.

Sehubungan dengan introduksi udang $L$. stylirostris maka perlu diketahui lebih pasti kemungkinan infeksi virus SEMBV terhadap udang tersebut sehingga dapat dirancang teknologi pembesarannya untuk menghindari kerugian sebagaimana terjadi pada udang windu.

Tabel 1. Uji patogenisitas virus SEMBV terhadap udang windu dan udang Litopenaeus stylirostris

\begin{tabular}{|c|c|c|c|c|c|c|c|c|c|c|c|c|c|}
\hline \multirow[t]{2}{*}{ Udang } & \multirow[t]{2}{*}{ Metode } & \multirow{2}{*}{$\begin{array}{c}\mathrm{N} \\
\text { ekor }\end{array}$} & \multicolumn{11}{|c|}{ Mortalitas kumulatif pasca perlakuan jam ke .. (ekor/\%) } \\
\hline & & & 1 & 3 & 6 & 12 & 24 & 48 & 72 & 96 & 120 & 144 & 168 \\
\hline \multirow{6}{*}{$\begin{array}{l}\text { Penaeus } \\
\text { monodon }\end{array}$} & Injeksi & 30 & 4 & 5 & 5 & 5 & 5 & 9 & 28 & 28 & 30 & 30 & 30 \\
\hline & & $\%$ & 13 & 16.7 & 16.7 & 16.7 & 16.7 & 30 & 93 & 93 & 100 & 100 & 100 \\
\hline & Kontrol & 10 & 0 & 0 & 0 & 0 & 0 & 0 & 0 & 0 & 0 & 0 & 0 \\
\hline & Pakan & 10 & 0 & 0 & 0 & 0 & 0 & 0 & 1 & 1 & 3 & 6 & 9 \\
\hline & & $\%$ & 0 & 0 & 0 & 0 & 0 & 0 & 10 & 10 & 30 & 60 & 90 \\
\hline & Kontrol & 10 & 0 & 0 & 0 & 0 & 0 & 0 & 0 & 0 & 0 & 0 & 0 \\
\hline \multirow{6}{*}{$\begin{array}{l}\text { Litopenaeus } \\
\text { stylirostris }\end{array}$} & Injeksi & 30 & 1 & 3 & 3 & 3 & 3 & 22 & 30 & 30 & 30 & 30 & 30 \\
\hline & & $\%$ & 3.3 & 10 & 10 & 10 & 10 & 73 & 100 & 100 & 100 & 100 & 100 \\
\hline & Kontrol & 10 & 0 & 0 & 0 & 0 & 0 & 0 & 0 & 0 & 0 & 0 & 0 \\
\hline & Pakan & 30 & 0 & 0 & 0 & 0 & 0 & 4 & 4 & 18 & 28 & 28 & 30 \\
\hline & & 100 & 0 & 0 & 0 & 0 & 0 & 13 & 13 & 60 & 60 & 60 & 100 \\
\hline & Kontrol & 10 & 0 & 0 & 0 & 0 & 0 & 0 & 0 & 0 & 0 & 0 & 0 \\
\hline
\end{tabular}


Hasil pengujian tingkat sensitifitas menunjukkan bahwa udang Litopenaeus stylirostris yang makan udang terinfeksi mengalami kematian setelah 48 jam, dan terjadi kematian total populasi setelah 168 jam, sedangkan udang windu mengalami kematian setelah 72 jam dan mengalami kematian total lebih dari 168 jam. Hasil transmisi hingga menghasilkan kematian $100 \%$ dilaporkan terjadi pada 120 jam pasca perlakuan untuk udang windu dan 168 jam untuk udang Penaeus indicus (Hameed et al., 1998). Kerentanan udang rostris (Litopenaeus stylirostris) terhadap serangan penyakit bercak putih juga telah dilaporkan oleh Nunan et al., (1998) yang mendapatkan penularan udang karena adanya impor udang dari Asia yang terinfeksi oleh SEMBV.

Tingkat kematian udang L. stylirostris yang relatif lebih cepat dibanding dengan udang windu kemungkinan disebabkan karena sifat kanibalisme dari udang ini. Infeksi virus selain dari pakan yang terkontaminasi juga karena udang memakan udang lain yang mati terlebih dahulu sehingga terjadi infeksi ganda.

Dengan melihat tingkat kerentanan udang L. stylirostris terhadap virus SEMBV, maka sistem budidaya udang ini harus dilakukan dengan sistem resirkulasi air tertutup. Disamping benih yang ditebar harus bebas virus, maka lingkungan harus dibebaskan dari virus beserta kariernya seperti halnya pada sistem budidaya udang windu.

Pemilahan benih harus dilakukan dengan PCR, karena teknik ini merupakan teknik yang paling sensitif untuk deteksi virus pada tingkatan yang paling dini. Teknik pemilahan benih dengan PCR juga telah terbukti efektif mengendalikan wabah penyakit bercak putih pada budidaya udang windu dan telah direkomendasikan di beberapa negara, seperti Thailand, Filipina dan Australia. Sistem desinfeksi lingkungan dari karier virus dapat dilakukan dengan pemberian kaporit dengan dosis $40 \mathrm{ppm}$, atau penggunaan pestisida krustasid.

\section{Daftar Pustaka}

Hameed, A.S.S., M. Anilkuma, M.L.S. Raj and K. Jayaraman. 1998. Studies on the pathogenicity of systemic ectodermal and mesodermal baculovirus and its detection in shrimp by immunological methods. Aquaculture 160: 31-48.

Lo, C.F, Y.S. Chang, C.T. Cheng and G.H. Kou. 1998. PCR monitoriing of cultured shrimp for white spot syndrome virus (WSSV) infection in growout ponds. In: Flegel, T. W. (Ed.). Advances in shrimp biotechnology: Proceedings to the special session on shrimp biotechnology $5^{\text {th }} \quad$ Asian Fisheries Forum Chiengmai, Thailang 11-14 November 1998. Pp.: 281-286.

Nunan, L.M., B.T. Poulos, and D.V. Lightner. 1998. The detection of White Spot Syndrome Virus (WSSV) and Yellow Head Virus (YHV) in imported commodity shrimp. Aquaculture 160:1930 